\title{
Microbially Promoted Solubilization of Steel Corrosion Products and Fate of Associated Actinides
}

(Project Number: 64931)

\section{Principal Investigator}

Yuri A. Gorby

Pacific Northwest National Laboratory

P.O. Box 999, MSIN P7-50

Richland, WA 99352

509-373-6177 (phone)

509-376-1321 (fax)

yuri.gorby@pnl.gov

\section{Co-Investigators}

Gill G. Geesey

Montana State University

Center for Biofilm Engineering

409 Cobleigh Hall

Bozeman, MT 59717

406-994-4770 (phone)

gill_g@erc.montana.edu

Frank Caccavo, Jr.

Whitworth College

Department of Biology

Mail Stop 3902

$300 \mathrm{~W}$. Hawthorne Road

Spokane, WA 99251

509-777-4576 (phone)

fcaccavo@whitworth.edu

James K. Fredrickson

Pacific Northwest National Laboratory

P.O. Box 999, MSIN P7-50

Richland, WA 99352

509-373-6177 (phone)

509-376-1321 (fax)

jim.fredrickson@pnl.gov 


\section{Research Objective}

The U.S. Department of Energy (DOE) statements of need call for "biological and physical chemical parameters for effective decontamination of metal surfaces using environmentally benign aqueous-based biopolymer solutions and microbial processes with potential for decontaminating corroding metal surfaces." Improved understanding of the fundamental processes of microbial reductive dissolution of iron oxide scale on corroding carbon steel will support assessment and potential application of an environmentally benign and cost-effective strategy for in situ decontamination of structural metal surfaces and piping.

This research is designed to develop a safe and effective biological approach for decontaminating mild and stainless steels that were used in the production, transport, and storage of radioactive materials.

\section{Research Progress and Implications}

This report summarizes research progress made during the 3-year tenure for this project. An extension with minimal carryover funds was requested and granted to complete and submit manuscripts for publication. During this research, we have

- Demonstrated that $\mathrm{Fe}(\mathrm{III})$-reducing bacteria reduce $\mathrm{Pu}(\mathrm{IV})$ (insoluble) to $\mathrm{Pu}(\mathrm{III})$ (soluble).

- Confirmed that the bacteria sorb and accumulate trivalent cations, such as $\mathrm{Pu}(\mathrm{III})$.

- Demonstrated that bacteria attached to oxide surfaces are very difficult to remove. Concluded that recovery of bacteria with sorbed Pu(III) would be impractical.

- Demonstrated that Fe(II) and reduced quinone-like compounds, which are both products of anaerobic respiration, can reduce chemically reduce solid $\mathrm{Pu}(\mathrm{IV})$ to dissolved $\mathrm{Pu}(\mathrm{III})$.

- Conceptualized a bead-based system that effectively removes Pu from iron oxides and accumulates Pu(III) in beads of sodium alginate that can be easily separated from the bulk aqueous phase.

Dissimilatory iron-reducing bacteria enzymatically reduce and dissolve iron oxides, which are common components of corrosion films, and release soluble species of plutonium, $\mathrm{Pu}(\mathrm{III})$. Consistent with our previous hypothesis, cell surfaces sorb $\mathrm{Pu}(\mathrm{III})$ and remove it from the bulk aqueous phase. However, we incorrectly hypothesized that bacteria with sorbed actinides could be easily detached and recovered from the surfaces that they had colonized and enzymatically altered. In fact, we have demonstrated that although cells do naturally detach from oxide 
surfaces during their growth cycle, they leave behind negatively charged reactive portions of their outer surface that are strong sorbants for cations. Without a means for recovering both intact bacteria, their subcellular products and associated contaminants, the use of iron-reducing bacteria for decontaminating corroded steel surfaces would not be feasible. Hence, we have targeted an approach that avoids direct contact and attachment of cells to the corrosion films but allows for reduction, dissolution, and sorption of corrosion products and associated actinides.

\section{Description of Bead-Based Treatment}

Iron reducing bacteria are encapsulated in small beads of sodium alginate. Encapsulation prevents direct contact between the bacteria and the contaminated oxide surface. Anthraquinone disulfonate (AQDS) is used as a dissolved electron shuttle to carry electrons from the bacteria to $\mathrm{Fe}(\mathrm{III})$ and $\mathrm{Pu}(\mathrm{IV})$ on the corrosion film. AQDS reduces $\mathrm{Fe}(\mathrm{III})$ to $\mathrm{Fe}(\mathrm{II})$ and $\mathrm{Pu}$ (IV) to $\mathrm{Pu}$ (III). The reduced forms of these metals are very soluble and partition to the aqueous phase. The bacterial surface and the sodium alginate sorb and accumulate Fe(II) and Pu(III). The beads, which now contain most of the $\mathrm{Pu}(\mathrm{III})$, can be easily separated from the bulk aqueous phase. The benign process requires no hazardous chemicals or extreme $\mathrm{pH}$ conditions.

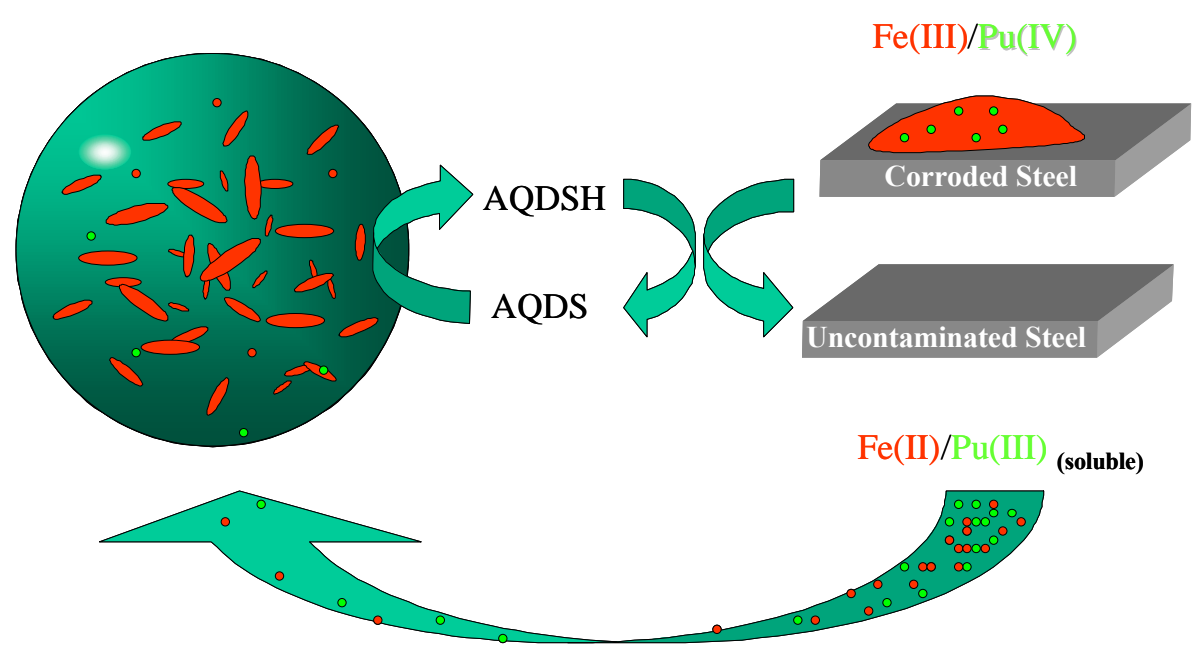

Figure 1. This illustrates a conceptual model of a bead-based system for decontaminating corroded steels. Metal-reducing bacteria are enrobed in porous alginate beads. Oxidized anthraquinone disulfonate, AQDS, which will serve as a dissolved electron shuttle between immobilized cells and elements in the corrosion film, diffuses into the beads and is enzymatically reduced by the bacteria. The reduced AQDSH diffuses out of the bead and chemically reduces and dissolves $\mathrm{Fe}(\mathrm{III})$ and $\mathrm{Pu}(\mathrm{IV})$ in the corrosion film. Soluble $\mathrm{Fe}(\mathrm{II})$ and $\mathrm{Pu}$ (III) sorb to cationic exchange sites within the alginate beads. The beads and accumulated actinides can then be easily separated from the bulk aqueous phase and the uncontaminated steel. 
Carryover funds were insufficient to evaluate the bead-based system for removing Pu from contaminated corrosion. However, the system was tested for its ability to remove dissolved radionuclides (uranium and technetium) from aqueous media. Figure 2 illustrates that ironreducing bacteria embedded in a porous alginate matrix reduce dissolved $\mathrm{Tc}(\mathrm{VII})$ (as pertechnetate ion) to poorly soluble $\mathrm{TcO}_{2}$. Vials 1 and 2 contain alginate beads that are blackened by $\mathrm{TcO}_{2}$ precipitates. Vial 3 served as a control and contains beads with no cells. All of the Tc(VII) remained in the aqueous phase. Vials containing dissolved U(VI) in lieu of $\mathrm{Tc}(\mathrm{VII})$ yielded similar results. These results clearly demonstrate the potential for removing dissolved radionuclides from solution using an environmentally benign bead-based approach.

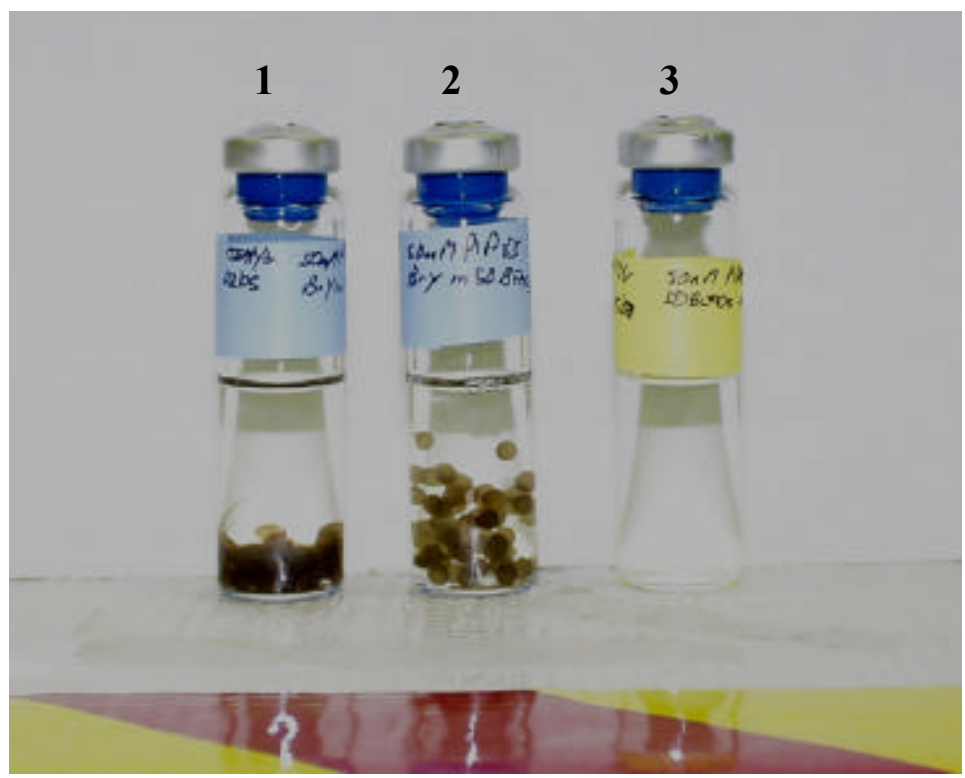

Figure 2. Vials demonstrating the ability of iron-reducing bacteria in alginate beads to remove dissolved $\mathrm{Tc}(\mathrm{VII})$ from solution. $100 \mu \mathrm{M}$ of $\mathrm{Tc}(\mathrm{VII})$ were reduced and precipitated within the beads in vials 1 and 2 . Vial 3 served as a negative control and lacked bacterial cells. Beads without bacteria are difficult to see because they contain none of the dark Tc(IV) precipitate.

\section{Information Access}

Rai D, YA Gorby, JK Fredrickson, DA Moore, and M Yui. 2002. Reductive Dissolution of $\mathrm{PuO}_{2}(\mathrm{am})$ : The Effect of Fe(II) and Hydroquinone. J. Sol. Chem. (in press).

Gorby YA, J Mclean, A Dohnalkova, A Korenevsky, K Rosso, E Vinogradov, and TJ Beveridge. 2002. Membrane vesicles form the dissimilatory iron reducing bacterium Shewanella putrefaciens strain CN32. FEMS Microbial. Lett. (in review).

Das A and F Caccavo, Jr. 2001. Adhesion of the dissimilatory Fe(III) - Reducing bacterium Shewanella alga BrY to crystalline Fe(III) oxides. Curr. Microbiol. 42:151-154 
Caccavo F and A Das. 2002. Adhesion of Dissimilatory Fe(III)-Reducing Bacteria to Fe(III) Minerals. Geomicrobiol. J. 19:161-177.

Das A and F Caccavo, Jr. 2000. Dissimilatory Fe(III) oxide reduction by Shewanella alga BrY requires adhesion. Curr. Microbiol. 40:344-347. 